\section{Tindak Pidana Penyerobatan Tanah Dalam Perspektif Hukum Pidana}

Oleh :

\section{Mhd. Ridwan Lubis}

\section{Abstract}

The title of this Journal is "The Crime of Land Grabbing in a Criminal Law Perspective". The research problems studied in this thesis are how to regulate the crime of land grabbing, how is law enforcement against the crime of land grabbing. The research method used in this research is to use normative juridical research sourced from library research using secondary data which consist of primary legal materials, secondary legal materials and tertiary legal materials.

The result of the research shows that the regulation of thecrime of land grabbingis regulated in a number of provisions concerning the crime of land grabbing which is regulated in some provisions of the legislation, including Law Number 51 Prp. 1960 states that the use of land without a permit with the right or legal power is prohibited and punishable by criminal penalties (Article 2 and Article 6) and it is regulated in the Criminal Code in several articles, namely Article 167, Article 242, Article 263, Article 264, Article 266, Article 274, and Article 385 of the Criminal Code.. Law enforcement against the crime of land grabbing is subject to Article 385 of the Criminal Code which is the only article directly related to the land grabbing and is categorized as a criminal offense. Particularly in Article 385 paragraph (1) of the Criminal Code which reads: "whoever with the intention of illegally benefiting himself or another person, sells, exchanges or burdens with credietverbandsomething right to Indonesian land, a building, construction, planting or seeding, even though it is known that it is someone else who owns or shares rights over it.

Keywords : Crime, Land Grabbing, Criminal Law.

\section{Abstrak}

Tindak Pidana Penyerobatan Tanah dalam Perspektif Hukum Pidana". Rumusan masalah yang dikaji dalam penelitian ini adalah bagaimana pengaturan tindak pidana penyerobotan tanah, bagaimana penegakan hukum terhadap tindak pidana penyerobotan tanah. Metode penelitian yang dipergunakan dalam penelitian ini adalah menggunakan penelitian yuridis normatif bersumber dari studi pustaka (library research) menggunakan data sekunder terdiri dari bahan hukum primer, bahan hukum sekunder dan bahan hukum tersier.

Hasil penelitian bahwa pengaturan tindak pidana penyerobotan tanah diatur dalam beberapa ketentuan pengaturan tindak pidana penyerobotan tanah diatur dalam beberapa ketentuan peraturan perundang-undangan, diantaranya Undang-Undang Nomor 51 Prp. Tahun 1960 menyatakan bahwa pemakaian tanah tanpa izin yang berhak atau kuasanya yang sah adalah perbuatan yang dilarang dan diancam dengan hukuman pidana (Pasal 2 dan Pasal 6) serta diatur dalam Kitab UndangUndang Hukum Pidana pada beberapa pasal yaitu Pasal 167, Pasal 242, Pasal, Pasal 263, Pasal 264, Pasal 266, Pasal 274, serta Pasal 385 KUHP. Penegakan hukum terhadap tindak pidana penyerobotan tanah adalah dikenakan Pasal 385 KUHP yang merupakan satu-satunya pasal yang langsung terkait penyerobotan tanah dan dikatagorikan sebagai tindak pidana kejahatan. Khususnya pada Pasal 385 ayat (1) KUHP yang berbunyi : "barang siapa dengan maksud menguntungkan diri sendiri atau orang lain secara melawan hukum, menjual, menukarkan atau membebani dengan crediet verband sesuatu hak atas tanah Indonesia, sesuatu gedung, bangunan, penanaman atau pembenihan, padahal diketahui bahwa yang mempunyai atau turut mempunyai hak atasnya adalah orang lain.

Kata Kunci : Kejahatan, Perampasan Tanah, Hukum Pidana 
Media Komunikasi dan Informasi Hukum dan Masyarakat

\section{Pendahuluan}

\section{A. Latar Belakang}

Penyerobotan tanah merupakan perbuatan mengambil hak atau harta dengan sewenang-wenang atau dengan tidak mengindahkan hukum dan aturan, seperti menempati tanah atau rumah orang lain yang bukan merupakan haknya.. Tindakan penyerobotan lahan secara tidak sah merupakan perbuatan yang melawan hukum, yang dapat digolongkan sebagai suatu tindak pidana. $^{1}$

Penyerobotan tanah bukanlah suatu hal yang baru di Indonesia dan dalam kehidupan sehari-sehari tentu banyak berbagai peristiwa yang terjadi, salah satunya adalah penyerobotan dan pengrusakan tanah milik orang lain, baik di sengaja maupun tidak di sengaja di Indonesia. Penyerobotan tanah oleh seseorang atau sekelompok orang terhadap tanah milik orang lain sering terjadi di berbagai daerah di Indonesia.

Penyerobatan tanah dalam realitanya di Indonesia merupakan hal yang sulit dihindari apalagi di wilayah kota metropolitan sekarang, dimana tanah kosong semakin sulit ditemukan tetapi para pendatang makin banyak berdatangan untuk mempertaruhkan nasib mereka meskipun tidak memiliki tempat tinggal yang jelas maupun sanak keluarga dan hal tersebutlah yang mendorong begitu banyaknya terjadi penyerobotan lahan negara maupun lahan yang dikuasai perorangan atau perusahaan. Hal tersebut sering didapati dimana bagunan-bangunan liar yang dapat

1 Ivor Ignasio Pasaribu, "Penyerobotan Tanah Secara Tidak Sah Dalam Perspektif Pidana", tersedia pada http://www.hukumproperti.com, diakses pada hari Senin 18 Mei 2020 Pukul 21.00 Wib. disaksikan yang biasanya berada di lahan-lahan kosong untuk menjadi tempat berteduh bagi yang terus berjuang untuk tetap mempertahankan hidupnya dengan terpaksanya harus menyerobot lahan yang bukan haknya dan di dalam KUHP telah jelas diatur pada Pasal 385 dengan maksimal hukaman 4 (empat) tahun penjara.

Sanksi penyerobotan dan pengerusakan juga diatur dalam Pasal 2 Peraturan Pemerintah Pengganti UndangUndang Nomor 51 Tahun 1960 tentang Larangan Pemakaian Tanah Tanpa Izin yang Berhak atau Kuasanya menentukan: Dilarang memakai tanah tanpa izin yang berhak atau kuasanya yang sah. Jika ketentuan ini dilanggar, maka dapat dipidana dengan hukuman kurungan selama-lamanya 3 (tiga) bulan dan/atau denda sebanyak-banyaknya Rp. 5.000,- (lima ribu rupiah), sebagaimana dimaksud ketetuan Pasal 6. Ketentuan Pasal 6 juga berlaku untuk perbuatan:

1. Mengganggu yang berhak atau kuasanya yang sah didalam menggunakan haknya atas suatu bidang tanah;

2. Menyuruh, mengajak, membujuk atau menganjurkan dengan lisan atau tulisan untuk melakukan perbuatan yang dimaksud pada huruf a dan $b$;

3. Memberi bantuan dengan cara apapun juga untuk melakukan perbuatan tersebut pada Pasal 2 atau huruf $b$.

Kasus penyerobotan lahan juga dapat terjadi tindak pidana lainnya seperti :

1. Pasal 170, Pasal 406 dan Pasal 412 : Perusakan barang, pagar, bedeng, plang, bangunan dan lain-lain.

2. Pasal 263, Pasal 264, Pasal 266 KUHP : Pemalsuan dokumen/akta/surat yang berkaitan dengan tanah.

Kendala dalam penanganan kasus tindak pidana penyerobotan tanah harus segera 
Media Komunikasi dan Informasi Hukum dan Masyarakat

diatasi dengan menegakkan hukum di masyarakat. Suatu masyarakat tanpa hukum tidak akan pernah menjadi masyarakat yang baik dan dalam masyarakat yang tradisional pun pasti ada hukum dengan bentuk dan corak yang sesuai dengan tingkat peradaban masyarakat tersebut. $^{2}$ Hukum mengatur tindakan atau perbuatan apa saja yang tidak boleh dilakukan berikut dengan sanksinya apabila dilanggar. Hukum bersifat memaksa, dengan adanya sanksi tersebut, sehingga dalam bertindak, masyarakat akan lebih berhati-hati, apakah tindakannya tersebut merugikan pihak lain atau tidak.

Penegakan hukum terhadap kasus tindak pidana penyerobotan tanah, harus pula mengutamakan nilai-nilai keadilan, selain kepastian hukum dan kemanfaatan. Tanah yang tidak digunakan oleh negara yang kemudian dimanfaatkan oleh warga, sehingga tanah tersebut tidak menjadi tandus dan rusak, tentunya apa yang dilakukan oleh warga harus pula dihargai dan tidak dapat dikesampingkan begitu saja.

Penegakan hukum dan keadilan dalam proses hukum yang adil atau yang berkeadilan adalah penegakan yang dijamin oleh UndangUndang Dasar Negara Republik Indonesia Tahun 1945 yang memberikan perlindungan dan manfaat bagi setiap warga negara dalam rangka tegaknya supremasi konstitusi sebagai hukum dasar negara. Oleh karena itu, rangkaian asas-asas proses hukum yang adil dan lengkap, baik dan sempurnanya Undang-Undang Dasar Negara Republik Indonesia Tahun 1945 dan peraturan perundang-undangan tidak banyak berarti bagi warga negara atau masyarakat

2 Bushar Muhammad, Pengantar Hukum Adat, Balai Buku Ichtiar, Jakarta, 2011, hal. 39. siapapun, kalau tidak ditegakkan atau diterapkan secara benar dan adil, serta akan menimbulkan citra buruk bagi Indonesia sebagai negara hukum yang demokratis (rechtstaaten democratische). ${ }^{3}$

Dengan latar belakang uraian di atas, maka penulis tertarik untuk meneliti dan menulis tentang "Tindak Pidana Penyerobatan Tanah dalam Perspektif Hukum Pidana”.

\section{B. Perumusan Masalah}

Permasalahan dalam penulisan ini adalah sebagai berikut:

1. Bagaimana pengaturan tindak pidana penyerobotan tanah ?

2. Bagaimana penegakan hukum terhadap tindak pidana penyerobotan tanah ?

\section{Metode Penelitian}

Penelitian merupakan sarana pokok dalam pengembangan ilmu pengetahuan maupun teknologi. Hal ini disebabkan karena penelitian bertujuan untuk mengungkapkan kebenaran secara sistematis, metodologi dan konsisten. Melalui proses penelitian tersebut diadakan analisa dan konstruksi data yang telah dikumpulkan. ${ }^{15}$

Jenis penelitian yang dilakukan adalah penelitian yuridis normatif. ${ }^{17}$ Penelitian yuiridis normatif yaitu penelitian yang difokuskan untuk mengkaji penerapan kaedah-kaedah atau norma-norma hukum positif. Mengambul istilah Ronald Dworkin, penelitian semacam ini disebut dengan istilah penelitian doktrinal (doctrine research) yaitu penelitian yang menganalisis hukum, baik yang tertulis maupun tidak tertulis

${ }^{3}$ Abdul Latif, Hukum Administrasi Dalam Praktik Tindak Pidana Korupsi, Kencana Prenada Media, Jakarta, 2014, hal. 180

${ }^{15}$ Soerjono Soekanto, Pengantar Penelitian Hukum, UI Press, Jakarta, 2016, hal..3

${ }^{17}$ Jhony Ibrahim, Teori dan Metodologi Penelitian Hukum Normatif, Bayumedia, Surabaya, 2008, hal.295 
Media Komunikasi dan Informasi Hukum dan Masyarakat

di dalam buku(law at it is written in the book) maupun hukum yang diputuskan oleh hakim melalui proses pengadilan(law is it decided by the judge through judicial process). ${ }^{18}$ Penelitian yuridis sosiologis yaitu penelitian yang bertitik tolak dari permasalahan dengan melihat kenyataan yang terjadi di lapangan kemudian menghubungkan dengan peraturan perundangundangan yang berlaku.

Sifat penelitian ini adalah bersifat deskriptif analitis, penelitian bersifat deskriptif analitis merupakan suatu penelitian yang menggambarkan, menelaah, menjelaskan dan menganalisis suatu peraturan hukum.

\section{Hasil dan Pembahasan}

\section{A. Pengaturan Tindak Penyerobotan Tanah}

Tindak pidana merupakan pengertian dasar dalam hukum pidana (yuridis normatif). Kejahatan atau perbuatan jahat dapat diartikan secara yuridis atau kriminologis. Kejahatan atau perbuatan jahat dalam arti yuridis normatif adalah perbuatan seperti yang terwujud inabstracto dalam peraturan pidana. Sedangkan kejahatan dalam arti kriminologis adalah perbuatan manusia yang menyalahi norma yang hidup di masyarakat secara konkrit. Tindak pidana adalah suatu kelakuan manusia diancam pidana oleh peraturan undang-undang, jadi suatu kelakuan yang pada umumnya dilarang dengan ancaman pidana. ${ }^{4}$

Tindak pidana penyerobotan tanah oleh seseorang atau sekelompok orang terhadap tanah milik orang lain dapat diartikan sebagai perbuatan menguasai, menduduki, atau

\footnotetext{
${ }^{18}$ Bismar Nasution, Metode Penelitian Hukum Normatif dan Perbandingan Hukum, Fakultas Hukum Universitas Sumatera Utara, 2013, hal.2.

4 Tri Andrisman, Asas-Asas dan Aturan Umum Hukum Pidana Indonesia, Universitas Lampung, Bandar Lampung, 2009, hal. 70.
}

mengambil alih tanah milik orang lain secara melawan hukum, melawan hak, atau melanggar peraturan hukum yang berlaku. Karena itu, perbuatan tersebut dapat digugat menurut hukum perdata ataupun dituntut menurut hukum pidana.

Peraturan Pemerintah Pengganti Undang-Undang Nomor 51 Tahun 1960 Tentang Larangan Pemakaian Tanah Tanpa Izin Yang Berhak Atau Kuasanya menyatakan bahwa pemakaian tanah tanpa izin yang berhak atau kuasanya yangsah adalah perbuatan yang dilarang dan diancam dengan hukuman pidana (Pasal 2 dan Pasal 6).

Pasal 2 Peraturan Pemerintah Pengganti Undang-Undang Nomor 51 Tahun 1960 Tentang Larangan Pemakaian Tanah Tanpa Izin Yang Berhak Atau Kuasanya yang berbunyi :

Dilarang memakai tanah tanpa ijin yang berhak atau kuasanya yang sah. Unsur Pasal 2 ini adalah :

a. Memakai tanah tanpa ijin;

b. Tanpa ijin yang berhak;

Pasal 6 Peraturan Pemerintah Pengganti Undang-Undang Nomor 51 Tahun 1960 Tentang Larangan Pemakaian Tanah Tanpa Izin Yang Berhak Atau Kuasanya yang berbunyi :

a. Dengan tidak mengurangi berlakunya ketentuan dalam Pasal 3, 4 dan 5, maka dapat dipidana dengan hukuman kurungan selama-lamauya 3 (tiga) bulan dan/atau denda sebanyak-banyaknya Rp. 5.000,- (lima ribu rupiah);

1) Barangsiapa memakai tanah tanpa ijin yang berhak atau kuasanya yang sah, dengan ketentuan, bahwa jika mengenai tanah perkebunan dan hutan dikecualikan mereka yang akan diselesaikan menurut Pasal 5 ayat 1 ; 
Media Komunikasi dan Informasi Hukum dan Masyarakat

2) Barangsiapa mengganggu yang berhak atau kuasanya yang sah didalam menggunakan haknya atas suatu bidang tanah;

3) Barangsiapa menyuruh, mengajak, membujuk atau menganjurkan dengan lisan atau tulisan untuk melakukan perbuatan yang dimaksud dalam Pasal 2 atau sub b dari ayat 1 pasal ini;

4) Barangsiapa memberi bantuan dengan cara apapun juga untuk melakukan perbuatan tersebut pada pasal 2 atau huruf $\mathrm{b}$ dari ayat 1 pasal ini;

b. Ketentuan-ketentuan mengenai penyelesaian yang diadakan oleh Menteri Agraria dan Penguasa Daerah sebagai yang dimaksud dalam pasal 3 dan 5 dapat memuat ancaman pidana dengan kurungan selama-lamanya 3 (tiga) bulan dan/atau denda sebanyakbanyakrrya Rp 5.000,- (lima ribu rupiah) terhadap siapa yang melanggar atau tidak memenuhnya.

c. Tindak pidana tersebut dalam pasal ini adalah pelanggaran.

Unsur Pasal 6 Peraturan Pemerintah

Pengganti Undang-Undang Nomor 51 Tahun 1960 Tentang Larangan Pemakaian Tanah

Tanpa Izin Yang Berhak Atau Kuasanya adalah:

a. Barang siapa;

b. Memakai tanah tanpa ijin;

c. Mengenai tanah perkebunan;

d. Haknya atas suatu bidang tanah;

e. Memberi bantuan dengan cara apapun.

Kejahatan terhadap penyerobotan tanah juga diatur dalam Kitab Undang-Undang Hukum Pidana (KUHP), yang diatur dalam beberapa pasal dalam KUHP, di antaranya :

Pasal 167 KUHP:

(1) Barang siapa memaksa masuk ke dalam rumah, ruangan atau pekarangan tertutup yang dipakai orang lain dengan melawan hukum, atau berada di situ dengan melawan hukum, dan atas permintaan yang berhak atau suruhannya tidak pergi dengan secara diancam dengan pidana pedana paling lama sembilan bulan atau denda paling banyak tiga ratus rupiah;
(2) Barang siapa masuk dengan merusak atau memanjat, dengan menggunakan anak kunci palsu perintah palsu atau pakaian jabatan palsu atau barang siapa tidak setahu yang berhak lebih dahulu serta bukan karena kehkilafan masuk dan kedapatan di situ pada waktu malam, dianggap memaksa masuk;

(3) Jika mengeluarkan ancaman atau menggunakan sarana yang dapat menakutkan orang pidana menjadi paling lama satu tahun empat bulan;

(4) Pidana tersebut dalam ayat I dan 3 dapat ditambah sepertiga jika yang melakukan kejahatan dua orang atau lebih dengan bersekutu.

Unsur Pasal 167 KUHP :

a. Barang siapa;

b. Unsur mereka yang dengan memberi atau menjanjikan sesuatu, dengan menyalahgunakan kekuasaan atau martabat, dengan kekerasan, ancaman atau penyesatan, atau dengan memberikan kesempatan, sarana atau keterangan , sengaja menganjurkan orang lain supaya melakukan perbuatan;

c. Unsur memaksa masuk ke dalam rumah, ruangan atau pekarangan tertutup yang dipakai orang lain atau berada disitu dengan melawan hukum;

d. Unsur dengan melawan hukum;

e. Unsur atas permintaan yang berhak atau suruhannya tidak pergi dengan segera;

Pasal 242 KUHP, yang berupa kejahatan terhadap pernberian sumpah palsu dan keterangan palsu antara lain:

(1) Barang siapa dalam hal dimana undang-undang menentukan supaya memberi keterangan di atas sumpah, atau mengadalian akibat hukum kepada keterangan yang demikian, dengan sengaja memberi keterangan palsu di atas sumpah, baik dengan dasar, atau tulisan, olehnya sendiri maupun oleh kuasanya yang khusus ditunjuk untuk itu, diancam dengan pidana penjara paling lama tujuh tahun.

(2) Jika keterangan palsu di atas sumpah diberikan dalam perkara pidana dan merugikan terdakwa atau tersangka, yang bersalah dikenakan pidana penjara paling lama sembilan tahun. 
Media Komunikasi dan Informasi Hukum dan Masyarakat

(3) Disamakan dengan sumpah palsu adalah janji atau pengikatan, .yang diharuskan menurut aturan-aturan umum atau yang menjadi pengganti sumpah;

\section{Unsur Pasal 242 KUHP :}

a. Keterangan itu harus atas sumpah;

b. Keterangan itu harus diwajibkan menurut undang-undang atau menurut peraturan yang menentukan akibat hukum pada keterangan itu;

c. Keterangan itu harus palsu (tidak benar) dan kepalsuan ini diketahui oleh pemberi keterangan;

Berdasarkan aturan-aturan di atas, Pasal 385 KUHP adalah merupakan satusatunya pasal yang sering digunakan oleh pihak penyidik (Polisi) dan penuntut umum (Jaksa) untuk mendakwa "pelaku penyerobotan tanah" dan dikatagorikan sebagai tindak pidana kejahatan. Khususnya Pasal 385 ayat (1) KUHP yang berbunyi : "barang siapa dengan maksud menguntungkan diri sendiri atau orang lain secara melawan hukum, menjual, menukarkan atau membebani dengan crediet verband sesuatu hak atas tanah Indonesia, sesuatu gedung, bangunan, penanaman atau pembenihan, padahal diketahui bahwa yang mempunyai atau turut mempunyai hak atasnya adalah orang lain."

Tindak pidana penyerobotan tanah jika dilihat dari segi waktunya dibedakan menjadi dua, yaitu pada waktu perolehan dan pada waktu mengakui tanpa hak. Sehubungan dengan itu sekalipun seseorang disangka benar telah melakukan suatu tindak pidana penyerobotan tanah, akan tetapi hal itu tidak merupakan jaminan bahwa pelaku tersebut dapat dijatuhi hukuman, atau dengan kata lain tidak setiap orang yang melakukan kesalahan dapat dihukum sebelum benar-benar dinyatakan telah memenuhi segala syarat-syarat yang ditentukan dalam undang-undang.

Atas dasar itulah P.A.F. Lamintang mengatakan bahwa orang pelaku tindak pidana adalah "Tidak cukup apabila disitu hanya terdapat suatu strafbaarfeit, melainkan harus juga strafbaar persoon atau seseorang yang dapat dihukum apabila strafbaarfeit yang dilakukan itu tidak bersifat wederchttelijk dan telah dilakukan baik dengan sengaja maupun dengan tidak sengaja". 5

Tindak pidana ini pada waktu perolehan berlandaskan pada adanya tindak pidana penipuan yang diatur pada Pasal 385 KUHP, yang diberi kualifikasi sebagai stelionat atau dapat disebut penipuan yang berhubungan hak atas tanah. Ketentuan pidana pada pasal ini bertujuan untuk melindungi hak atas tanah yang dimiliki oleh penduduk asli berdasarkan hukum adat, ataupun atas bangunan-bangunan atau tanaman-tanaman yang terdapat di atas tanah.

Pasal 385 KUHP, pada pasal ini tersebut mengandung unsur-unsur sebagai berikut:

a. Unsur subyektif:

1) Dengan Maksud menguntungkan diri sendiri atau orang lain dan dengan melawan hukum;

Dengan maksud di sini memperlihatkan kehendak dari sipelaku untuk menguntungkan diri sendiri dan di lain pihak memperlihatkan pengetahuan atau kesadaran sipelaku bahwa ia melakukan tindakan memaksa dan seterusnya. Jadi dengan maksud menguntungkan diri sendiri atau orang lain secara melawan hukum berarti : sipelaku mengetahui bahwa untuk menguntungkan

${ }^{5}$ PAF. Lamintang dan Lamintang Theo, Delik-delik Khusus Kejahatan terhadap Harta Kekayaan, Sinar Grafika, Jakarta, 2009, hal. 174. 
Media Komunikasi dan Informasi Hukum dan Masyarakat

diri sendiri/orang lain tersebut adalah suatu tindakan yang bertentangan dengan hukum atau dengan hak orang lain. Kalau sipelaku tidak ada kehendak untuk menguntungkan diri sendiri atau orang lain, maka pasal yang lebih tepat diterapkan adalah Pasal 335 KUHP. Bahkan jika sipelaku yakin atau mengira bahwa ia berhak untuk menguntungkan diri sendiri/orang lain (misalnya sipelaku yakin bahwa bahwa barang itu adalah miliknya atau milik temannya yang baru saja hilang), maka unsur ini tidak terpenuhi dan karenanya penerapan pasal ini tidak tepat.

Bahwa maksud sipelaku adalah untuk menguntungkan diri sendiri/orang lain, harus terbukti. Tetapi apakah harus terbukti pula bahwa yang diperas itu harus merasa dirugikan, tidak dipersoalkan. Namun jika yang diperas itu memang merasa dirugikan, maka hal ini dapat digunakan untuk memperkuat maksud sipelaku. $^{6}$

Penggunaan istilah "dengan maksud" yang ditempatkan di awal perumusan berfungsi rangkap, yaitu baik sebagai pengganti dari kesengajaan maupun sebagai pernyataan tujuan. Sebagai unsur sengaja, maka sipelaku menyadari/menghendaki suatu keuntungan untuk diri sendiri/orang lain. Hal yang penting ialah, adakah ia pada waktu itu mengharapkan suatu keuntungan. Bahwa mungkin yang sebaliknya yang terjadi, misalnya sesuatu barang yang diberikan itu kemudian mengakibatkan bencana bagi sipelaku/orang lain, tidak dipersoalkan. ${ }^{7}$

${ }^{6}$ SR. Sianturi, Tindak Pidana di KUHP Berikut Uraiannya, Alumni AHAEM-PETEHAEM, Jakarta, 2009, hal. 616-617.

${ }^{7} \mathrm{lbid}$, hal. 632
2) Diketahui tanah tersebut ada orang lain yang lebih berhak;

Kejahatan-kejahatan tersebut didalam pasal ini biasa disebut kejahatan Stellionat, yang berarti "penggelapan hak atas barang-barang yang tidak bergerak" (onroerende goederen), misalnya : tanah, sawah, gedung, dll. Supaya dapat dikenakan pasal ini, maka terdakwa harustelah nyata berbuat hal mengetahui, bahwa yang berhak atau ikut berhak disitu adalah orang lain. ${ }^{8}$

3) Tidak memberitahukan kepada orang lain bahwa tanah tersebut telah dijadikan tanah tanggungan utang atau telah digadaikan.

Unsur ini lebih menekankan pada kegiatan menjual, menukar atau membebani dengan suatu pinjaman sebidang tanah (dengan hak menurut UUPA), bangunan, dan sebagainya, padahal tanah tersebut sebelumnya sudah dibebankan dengan suatu pinjaman. Dengan perkataan lain terjadi dua kali pembebanan untuk sebidang tanah yang sama. $^{9}$

b. Unsur obyektif:

1) Barang siapa;

Sesuai dengan Pasal 9 UU No.5 Tahun 1960 (UUPA), maka yang dimaksud dengan "barangsiapa" pada sub ayat ke-1 sd ke-6 tersebut hanyalah warga negara Indonesia. ${ }^{10}$

2) Menjual, menukarkan, menyewakan atau menjadikan tanggungan utang sesuatu hak rakyat dalam memakai tanah pemerintah dan partikelir;

\footnotetext{
${ }^{8}$ R. Soesilo, KUHP Serta Komentar-komentarnya Lengkap Pasal demi Pasal, Politea, Bogor, 2006, hal. 266 ${ }^{9}$ SR. Sianturi, Op.Cit, hlm. 660. ${ }^{10}$ Ibid., hal. 661
} 
Media Komunikasi dan Informasi Hukum dan Masyarakat

Pasal ini dibuat pada tahun 1915 dan mulai berlaku tahun 1918, yang penerapannya dikaitkan dengan perundangan di bidang agraria (pertanahan) dan perundangan di bidang hukum dagang dan peminjaman uang. Beberapa perundangan yang berkaitan dengan : Suatu hak penggunaan sebidang tanah oleh rakyat Indonesia di atas tanah-negara (landsdomein) atau tanah-partikulir (particuliere landerijen) antara lain adalah :

a) Agrarische Wet (Stb.1870 no.55 jo Pasal 51 Stb.1925 No.447);

b) Domeinverklaring (tersebut pasal 1 Agrarisch Besluit Stb.1870 No.118);

c) Algemene Domeinverklaring (Stb.1875 No.119a);

d) Domeinverklaring lain-lainnya di luar Jawa;

e) Peraturan-peraturan pelaksanaan K.B. 16 April 1872 No.29 Stb.1872 No.117;

f) Buku II KUH Perdata sepanjang mengenai bumi dan sebagainya;

g) Bepalingen betreffende het Credietverband (KB.6 Juli 1908 No.50, Stb.1908 No.542 jo 1909 no.568).

Peraturan-peraturan di atas telah dicabut dengan Undang-Undang Pokok Agraria No.5 tahun 1960 (UUPA). Karenanya sebagai penyesuaiannya maka perkataan Credietverband pada Pasal 385 ini harus dibaca sebagai "pinjaman" dari Bank, sesuai dengan perundangan yang berlaku (termasuk perundangan hipotik). Sedangkan kalimat suatu hak-penggunaan sebidang tanah oleh rakyat Indonesia di atas tanah-negara (landsdomein) atau tanah partikulir harus dibaca sebagai "suatu hakpenggunaan sebidang tanah" sebagaimana diatur dalam UUPA.

3) Menggadaikan atau menyewakan tanah orang lain;

Ketentuan ini adalah untuk melindungi hak atas tanah yang dimiliki oleh penduduk asli berdasarkan Hukum Adat ataupun bangunan-bangunan atau tanaman-tanaman di atas tanah semacam itu. Sungguhpun benar, bahwa setelah berlakunya Undang-Undang Pokok Agraria tahun 1960 para camat itu ditunjuk sebagai Pejabat Pembuat Akta Tanah, sehingga seharusnya semua tindakan hukum yang menyangkut tanah itu dilakukan di depan camat setempat, akan tetapi didalam praktek banyak terjadi, bahwa hingga kinipun orang masih melakukan jual beli tanah di bawah tangan, bahkan dengan disaksikan oleh para pamong desa, umumnya dengan alasan "untuk sementara" sebelum menghadap camat untuk dilakukan jual beli secara resmi.

Sebelum tahun 1960 memang tidak ada satu peraturan yang berlaku secara umum di seluruh Indonesia tentang bagaimana orang Indonesia itu harus memindah tangankan tanah milik adatnya secara sah, dan karenanya cara tersebut diserahkan kepada Hukum Adat setempat dan umumnya dilakukan didepan Kepala Desa, walaupun cara itu sebenarnya adalah tidak diisyaratkan secara mutlak. Setelah tahun 1960 sudah jelas jual beli tanah secara itu adalah tidak sah. Di daerah pedalaman di desa-desa umumnya orang menganggap bahwa apa yang disebut "girik", "letter C" atau "surat pipil" itu adalah "bukti pemilikan tanah" yang sah., padahal sesungguhnya adalah tidak demikian. Suratsurat semacam itu hanyalah merupakan "tanda wajib pajak" dalam arti, bahwa orang yang namanya disebutkan di dalam surat semacam itu adalah orang yang wajib membayar pajak tanah. Ini tidak berarti bahwa orang yang membayar pajak itu 
Media Komunikasi dan Informasi Hukum dan Masyarakat

adalah orang yang mempunyai hak milik atas tanah yang pajak tanahnya ia bayar itu. $^{11}$

4) Menyewakan tanah buat suatu masa, sedang diketahuinya tanah tersebut telah disewakan sebelumnya kepada orang lain.

Unsur ini jauh lebih menunjukan kegiatan menyewakan sebidang tanah (dengan hak menurut UUPA) untuk waktu tertentu, padahal telah disewakan sebelumnya untuk waktu yang sama. ${ }^{12}$

Delik pelanggaran terhadap hak kebebasan dan ketentraman. Kejahatan ini dirumuskan dalam Pasal 167 KUHP, yang unsur-unsurnya sebagai berikut:

a. Unsur subyektif :

1) Melawan hukum yakni sebelum bertindak, ia sudah mengetahui atau sadar bahwa tindakannya bertentangan dengan hukum seolah-olah mengakui miliknya sendiri;

2) Sengaja yaitu ia telah mengetahui bahwa perbutannnya bertentangan dengan kewajiban hukumnya atau bertentangan dengan hak orang lain.

b. Unsur obyektif :

1) Dengan melawan hak masuk dengan paksa ke dalam rumah, ruangan tertutup, dan sebagainya; R. Soesilo mengatakan "masuk begitu saja" belum berarti "masuk dengan paksa". Yang artinya "masuk dengan paksa" ialah "masuk dengan melawan kehendak yang dinyatakan lebih dahulu dari orang yang berhak". ${ }^{13}$

11 PAF. Lamintang dan G. Djisman Samosir, Hukum Pidana Indonesia, Sinar Baru, Bandung, 2009, hal. 240-241.

${ }^{12}$ S.R.Sianturi, Op. Cit., hal. 662

${ }^{13}$ R. Soesilo, Op. Cit., hal. 145.
2) Dengan melawan hak berada di rumah, ruangan tertutup, dan sebagainya, tidak dengan segera pergidari tempat itu atas permintaan orang yang berhak atau atas nama orang yang berhak.

Jadi jika kehendak awal dari si pemilik rumah adalah memperbolehkan si pemegang kunci masuk jika terjadi sesuatu dan tidak ada orang di rumah, maka selain dari hal tersebut, si pemegang kunci tidak berhak untuk masuk ke dalam rumah itu. ${ }^{14}$

Bagian terpenting dari suatu sistem pemidanaan adalah menetapkan sanksi, keberadannya akan memberikan arah dan pertimbangan mengenai apa yang seharusnya dijadikan sanksi dalam suatu tindak pidana untuk menegakkan berlakunya norma. ${ }^{15}$ Dalam suatu peraturan perundang-undangan, adanya pengaturan tentang sanksi atau hukuman pidana menjadi hal yang sangat penting karena di dalam hukum pidana kita dapat mengetahui perbuatan-perbuatan mana yang tidak boleh dilakukan, dilarang, dan harus dilakukan dengan disertai ancaman atau sanksi yang berupa pidana tertentu bagi barang siapa yang melanggar ketentuan tersebut. ${ }^{16}$

Roeslan Saleh dalam Niniek Suparni menyatakan bahwa pidana adalah reaksi-reaksi atas delik yang berwujud suatu nestapa yang sengaja ditimpakan Negara kepada pembuat delik. ${ }^{68}$ Bambang Waluyo menyebutkan bahwa pidana adalah reaksi atas delik yang dijatuhkan harus berdasarkan pada vonis hakim melalui siding peradilan atas terbuktinya perbuatan

${ }^{14} \mathrm{lbid}$. , hal. 146.

15 Teguh Prasetyo dan Abdul Halim Barkatullah, Politik Hukum Pidana Kajian Kebijakan Kriminalisasi dan Dekriminalisasi, Pustaka Pelajar, Yogyakarta, 2005, hal. 82

${ }^{16}$ Djoko Prakoso, Pembaharuan Hukum Pidana di Indonesia, Liberty, Yogyakarta, 2017, hal. 19

${ }^{68}$ Ibid. hal. 22 
Media Komunikasi dan Informasi Hukum dan Masyarakat

pidana yang dilakukan. Apabila tidak terbukti bersalah maka tersangka harus dibebaskan. ${ }^{69}$

Berdasarkan pendapat para ahli yang dikemukakan di atas, maka suatu pidana harus:

1. Mengandung penderitaan atau konsekwensi lain yang tidak menyenangkan.

2. Dikenakan pada seorang yang benar-benar atau disangka benar melakukan tindak pidana

3. Dikenakan berhubung suatu tindak pidana yang melanggar ketentuan hukum

4. Dilakukan dengan sengaja oleh orang selain pelaku tindak pidana.

5. Dijatuhkan dan dilaksanakan oleh penguasa sesuai dengan ketentuan suatu system hukum yang dilanggar oleh tindak pidana tersebut. ${ }^{70}$

Penjatuhan pidana atau hukuman adalah merupakan reaksi sosial antara lain:

1. Terjadi berhubung dengan adanya pelanggaran terhadap suatu aturan hukum.

2. Dijatuhkan dan dilaksanakan oleh orang-orang yang berkuasa sehubungan dengan tertib hukum yang dilanggar.

3. Mengandung penderitaan atau paling tidak konsekwensi lain yang tidak menyenangkan.

4. Menyatakan pencelaan terhadap si pelanggar. ${ }^{71}$

Berdasarkan ruang lingkup

pemidanaan tersebut dapat diketahui bahwa

pidana selalu mengandung unsur-unsur:

1. Pada hakekatnya merupakan suatu pengenaan penderitaan atau nestapa atau akibat-akibat lain yang tidak menyenangkan.

2. Diberikan dengan sengaja oleh orang atau badan yang

69 Bambang Waluyo.Pidana dan Pemidanaan, Sinar Grafika, Jakarta, 2016, hal. 9.

70 Muladi,Lembaga Pidana Bersyarat, Alumni, Bandung, 2016, hal. 22

${ }^{71} \mathrm{lbid}$, hal. 22-23. mempunyai kekuasaan (oleh yang berwenang).

3. Dikenakan kepada seseorang yang telah melakukan tindak pidana menurut Undang-undang. ${ }^{72}$

Sebelum sanksi pidana yang dijatuhkan terhadap pelaku tindak pidana, terlebih dahulu terdapat berbagai teori yang membahas alasanalasan yang membenarkan (justification) penjatuhan hukuman (sanksi). Di antaranya adalah teori absolut dan teori relatif.

1. Teori absolut, (vergeldingstheorie). Menurut teori ini hukuman dijatuhkan sebagai pembalasan terhadap para pelaku karena telah melakukan kejahatan yang mengakibatkan kesengsaraan terhadap orang lain atau anggota masyarakat.

2. Teori Relatif (doeltheorie). Teori ini dilandasi oleh tujuan (doel) sebagai berikut :

a. Menjerahkan, dengan penjatuhan hukuman, diharapkan si pelaku atau terpidana menjadi jera dan tidak mengulangi lagi perbuatannya (speciale preventive) serta masyarakat umum mengetahui bahwa jika melakukan perbuatan sebagaimana dilakukan terpidana, mereka akan mengalami hukuman yang serupa (generale preventive).

b. Memperbaiki pribadi terpidana, berdasarkan perlakuan dan pendidikan yang diberikan selama menjalankan hukuman, terpidana merasa menyesal sehingga ia tidak akan mengulangi perbuatannya dan kembali kepada masyarakat sebagai orang yang baik dan berguna.

c. Membinasakan atau membuat terpidana tidak berdaya, membinasakan berarti menjatuhkan hukuman mati, sedangkan membuat terpidana tidak berdaya dilakukan dengan

\footnotetext{
${ }^{72} \mathrm{lbid}$, hal. 23
} 
Media Komunikasi dan Informasi Hukum dan Masyarakat

menjatuhkan hukuman seumur hidup. ${ }^{17}$

Menurut Pasal $10 \mathrm{KUHP}$, bahwa pidana terdiri atas:

1. Pidana Pokok:

a. Pidana mati;

b. Pidana penjara;

c. Pidana kurungan;

d. Pidana denda;

e. Pidana tutupan.

2. Pidana Tambahan:

a. Pencabutan hak-hak tertentu;

b. Perampasan barang-barang tertentu;

c. Pengumuman putusan hakim.

Perbuatan penyerobotan tanah yang dilakukan oleh seseorang dapat diproses dan dijerat dengan pasal-pasal yang terdapat dalam Undang-Undang Nomor 51 PRP Tahun 1960 tentang Larangan Pemakaian Tanah Tanpa Izin dan di dalam KUHP, antara lain : Pasal penyerobotan lahan (Jika pelaku menjual lahan milik orang lain yang sah), Pasal Pengancaman (Jika terdapat unsur ancaman dalam menyerobot lahan, Pasal Pemalsuan (Jika pelaku memalsukan surat menyurat yang ada), Pasal Perusakan (Jika Pelaku melakukan perusakan tanaman, pagar, patok kepunyaan pemilik yang sah, Pasal Penipuan (Jika terdapat unsur menipu orang lain dengan tipu muslihat dan melawan hukum.

Sesuai ketentuan Pasal 2 UndangUndang Nomor 51 PRP Tahun 1960 tentang Larangan Pemakaian Tanah Tanpa Izin yang masih berlaku hingga saat ini, bahwa seseorang yang memakai tanah tanpa izin yang berhak atau mengganggu pihak yang berhak maka

17 Leden Marpaung, Asas-Teori-Praktik Hukum Pidana, Sinar Grafika, Jakarta, 2005, hal. 4. diancam pidana kurungan paling lama tiga bulan.

Proses hukum sesuai ketentuan ini, penting adanya bukti aktifitas seseorang menanam tanaman, atau menggarap lahan atau mendirikan bangunan/gubuk di atas lahan milik orang lain. Proses pidana menggunakan acara cepat, dimana penyidik kepolisian bertindak sekaligus sebagai penuntut dalam persidangan yang dipimpin oleh Hakim Tunggal.

Sesuai ketentuan Pasal 368 ayat (1) KUHP, sesorang yang bermaksud menguasai lahan orang lain biasanya melakukan intimidasi dan ancaman kepada pemilik yang sah, dalam kondisi tersebut, hal ini dapat dipidana dengan syarat terdapat barang bukti berupa foto pada saat pelaku melakukan pengancaman (dengan ataupun tanpa senjata tajam) dan terdapat dua orang yang menyaksikan, yang seluruhnya atau sebagian adalah kepunyaan orang itu atau orang lain, atau supaya membuat hutang maupun menghapuskan piutang, diancam karena pemerasan, dengan pidana penjara paling lama sembilan tahun.

Selain itu, jika seseorang secara melawan hak memaksa orang lain untuk melakukan, tidak melakukan atau membiarkan sesuatu, dengan memakai kekerasan, atau dengan ancaman kekerasan, baik terhadap orang itu sendiri maupun orang lain dapat dikenakan Pasal 335 KUHP. Sesuai ketentuan ini, ancaman kekerasan (meski belum terjadi kekerasan) pun dapat dikenakan Pasal 335 KUHP jika unsur adanya paksaan dan ancaman ini terpenuhi. Proses pidana melalui delik aduan sang korban.

Sesuai ketentuan Pasal 385 Kitab Undang-Undang Hukum Pidana (KUHP), bahwa 
Media Komunikasi dan Informasi Hukum dan Masyarakat

seseorang yang secara melawan hukum, menjual, menukarkan tanah yang bukan miliknya kepada pihak lain dan memperoleh keuntungan atas perbuatannya tersebut, diancam pidana penjara paling lama empat tahun.

Dalam hal ini unsur yang harus dipenuhi yaitu adanya unsur "menguntungkan diri sendiri atau orang lain secara melawan hukum, menjual, menukarkan", yang berarti perbuatan seseorang yang menjual/menukarkan tanah yang bukan miliknya kepada pihak lain dan memperoleh keuntungan atas perbuatannya tersebut.

\section{B. Penegakan Hukum Terhadap Tindak Pidana Penyerobotan Tanah}

Penegakan hukum sebagai suatu proses pada hakikatnya merupakan penerapan diskresi yang menyangkut membuat keputusan yang tidak secara ketat diatur oleh kaidah hukum, akan tetapi mempunyai unsur penilaian pribadi. Dengan demikian pada hakikatnya diskresi berada diantara hukum dan moral (etika dalam arti sempit). ${ }^{18}$

Aspek penegakan hukum pidana terbagi atas dua bagian yaitu aspek penegakan hukum pidana materil dan aspek penegakan hukum pidana formil. Dari sudut dogmatis normatif, material atau substansi atau masalah pokok penegakan hukum terletak pada:

1. Faktor hukumnya sendiri.

2. Faktor penegak hukum yakni pihakpihak yang membentuk maupun menerapkan hukum.

3. Faktor sarana atau fasilitas yang mendukung penegakan hukum.

4. Faktor masyarakat yakni lingkungan dimana hukum tersebut berlaku dan diterapkan.

18 Soerjono Soekanto. Faktor-Faktor yang Mempengaruhi Penegeakan Hukum, Raja Grafindo Persada, Jakarta, 2014, hal. 7.
5. Faktor kebudayaan yakni sebagai hasil karya, cipta dan rasa yang didasarkan ada karsa manusia di dalam pergaulan hidup. ${ }^{19}$

Hukum pidana formil yang mengatur cara hukum pidana materil dapat dilaksanakan. Istilah penegak hukum adalah luas sekali, oleh karena mencakup mereka yang secara langsung dan secara tidak langsung berkecimpung di bidang penegakan hukum.

Hak sebenarnya merupakan wewenang untuk berbuat atau tidak berbuat, sedangkan kewajiban adalah tugas. Suatu peranan tertentu dapat dijabarkan ke dalam unsur-unsur sebagai berikut:

1. Peranan yang ideal (ideal role).

2. Peranan yang seharusnya (expected role)

3. Peranan yang dianggap oleh diri sendiri (perceived role)

4. Peranan yang sebenarnya dilakukan (actual role). ${ }^{20}$

Masalah pokok dari penegakan hukum sebenarnya terletak pada faktor-faktor yang mungkin mempengaruhinya. Faktor-faktor tersebut mempunyai arti yang netral, sehingga dampak positif atau negatifnya terletak pada isi faktor-faktor tersebut. Faktor-faktor tersebut antara lain :

1. Faktor hukumnya sendiri yaitu UndangUndang

2. Faktor pengak hukum yakni pihak-pihak yang membentuk maupun menerapkan hukum.

3. Faktor sarana atau fasilitas yang mendukung penegakan hukum

4. Faktor masyarakat yakni lingkungan dimana hukum tersebut berlaku atau diterapkan.

5. Faktor kebudayaan yakni sebagai hasil karya, cipta dan rasa yang didasarkan pada karsa manusia di dalam pergaulan hidup.

\footnotetext{
${ }^{19}$ lbid., hal.8.

${ }^{20}$ Ibid., hal.20.
} 
Media Komunikasi dan Informasi Hukum dan Masyarakat

Kejahatan yang semakin meningkat dan sering terjadi dalam masyarakat merupakan hal yang sangat diperhatikan, sehingga mengundang pemerintah (negara) sebagai pelayan, pelindung masyarakat untuk menanggulangi meluasnya dan bertambahnya kejahatan yang melanggar nilai-nilai maupun norma-norma yang hidup dan berlaku didalam suatu masyarakat sehingga kejahatan tersebut oleh negara dijadikan sebagai perbuatan pidana untuk tindak pidana. Hukum pidana merupakan sarana yang penting dalam penanggulangan kejahatan atau mungkin sebagai obat dalam memberantas kejahatan yang meresahkan dan merugikan masyarakat pada umunya dan korban pada khususnya

Berbicara tentang pertanggungjawaban pidana, maka tidak dapat dilepaskan dengan tindak pidana. Walaupun di dalam pengertian tindak pidana tidak termasuk pertanggungjawaban pidana. Tindak pidana hanya menunjuk pada dilarangnya suatu perbuatan. ${ }^{21}$

Dasar adanya tindak pidana adalah asas legalitas, sedangkan dasar dapat dipidananya pembuat adalah kesalahan. Ini berarti bahwa pembuat tindak pidana hanya akan dipidana jika ia mempunyai kesalahan dalam melakukan tindak pidana tersebut. Ini berarti bahwa pembuat tindak pidana hanya akan dipidana jika ia mempunyai kesalahan dalam melakukan tindak pidana tersebut. Berdasarkan hal tersebut, bahwa: Dipidananya seseorang tidaklah cukup apabila orang itu telah melakukan perbuatan yang bertentangan dengan hukum atau bersifat melawan hukum. Jadi meskipun perbuatan tersebut memenuhi

21 Teguh Prasetyo, Kriminalisasi dalam Hukum Pidana, Nusa Media, . Bandung, 2011, hal. 38. rumusan delik dalam undang-undang dan tidak dibenarkan (an objekctive breach of a panel provision), namun hal tersebut belum memenuhi syarat untuk penjatuhan pidana. ${ }^{22}$

Moeljatno mengartikan hukum pidana sebagai bagian dari keseluruhan hukum yang berlaku disuatu negara yang mengadakan dasar-dasar dan aturan-aturan untuk:

1. Menentukan perbuatan-perbuatan mana yang tidak boleh dilakukan, yang dilarang dengan disertai ancaman atau sanksi pidana tertentu bagi siapa saja yang melanggarnya.

2. Menentukan kapan dan dalam hal apa kepada mereka yang telah melakukan larangan-larangan itu dapat dikenakan dan dijatuhi pidana sebagaimana yang telah diancamkan.

3. Menentukan dengan cara bagaimana pengenaan pidana itu dapat dilaksanakan apabila orang yang diduga telah melanggar ketentuan tersebut. ${ }^{23}$

M. Hamdan, bahwa peristiwa pidana adalah suatu perbuatan atau rangkaian perbuatan manusia yang bertentangan dengan undang-undang atau peraturan perundangundangan lainnya terhadap perbuatan mana diadakan tindakan penghukuman. ${ }^{24}$

Mahrus Ali menyebutkan "strafbaarfeit adalah kelakuan yang diancam dengan pidana, bersifat melawan hukum, dan berhubung dengan kesalahan yang dilakukan oleh orang yang mampu bertanggung jawab. ${ }^{25}$ Frans Maramis menyebutkan tindak pidana adalah perbuatan yang pelakunya harusnya dipidana. ${ }^{26}$

Perbuatan yang melanggar hukum oleh subyek hukum yang bersifat memaksa dapat dikenakan sanksi. Penggunaan sanksi pidana sebagai salah satu sarana sanksi sosial dalam

\footnotetext{
${ }^{22} \mathrm{lbid}$.

${ }^{23}$ Moeljatno. Op.Cit, hal1.

${ }^{24}$ M. Hamdan.Op.Cit., hal.9

${ }^{25}$ Mahrus Ali, Op.Cit., hal.98.

${ }^{26}$ Frans Maramis. Op.Cit., hal.57.
} 
Media Komunikasi dan Informasi Hukum dan Masyarakat

segala keterbatasan, Bismar Siregar dalam buku Chairul Huda menyebutkan bahwa syaratsyarat penggunaan sanksi pidana secara optimal harus mencakup hal-hal:

1. Perbuatan yang dilarang tersebut menurut sebagian besar anggota masyarakat secara menyolok dianggap membahayakan masyarakat, dianggap penting oleh masyarakat.

2. Penerapan saksi pidana terhadap perbuatan yang dilarang, konsisten dengan tujuan-tujuan pemidanaan.

3. Pemberantasan terhadap perbuatan tersebut, tidak akan menghalangi atau merintangi perilaku masyarakat yang diinginkan.

4. Perilaku tersebut dapat dipahami melalui cara yang tidak berat sebelah dan tidak bersifat diskriminatif.

5. Pengaturannya melalui proses hukum pidana, tidak akan memberikan kesan memperberat, baik secara kualitatif maupun secara kuantitatif.

6. Tidak ada pilihan-pilihan yang beralaskan dari sanksi pidana tersebut, untuk menghadapi perilaku tersebut. $^{27}$

.Pertanggungjawaban pidana ditentukan berdasarkan pada kesalahan pembuat dan bukan hanya dengan dipenuhinya seluruh unsur tindak pidana. Dengan demikian kesalahan ditempatkan sebagai faktor penentu pertanggungjawaban pidana dan tak hanya dipandang sekedar unsur mental dalam tindak pidana. Seseorang dinyatakan mempunyai kesalahan merupakan hal yang menyangkut masalah pertanggungjawaban pidana. ${ }^{28}$

Mengenakan pidana pada pelaku karena melakukan tindak pidana, aturan hukum mengenai pertanggungjawaban pidana berfungsi sebagai penentu syarat-syarat yang harus ada pada diri seseorang sehingga sah jika

\footnotetext{
${ }^{27} \mathrm{Ibid}$., hal. 69

${ }^{28} \mathrm{Ibid}$., hal.72
}

dijatuhi pidana. Pertanggungjawaban pidana yang menyangkut masalah pembuat dari tindak pidana, aturan mengenai pertanggungjawaban pidana merupakan regulasi mengenai bagaimana memperlakukan mereka yang melanggar kewajiban. Perbuatan yang dilarang oleh masyarakat itu dipertanggungjawabkan pada sipembuatnya, artinya celaan yang objektif terhadap celaan itu kemudian diteruskan kepada terdakwa. Pertanggungjwaban pidana tanpa adanya kesalahan dari pihak yang melanggar tidak dapat dipertanggungjawaban. Orang yang tidak mungkin dipertanggungjawabkan dan dijatuhi pidananya kalau tidak melakukan perbuatan pidana.

Mempertanggungjawabkan perbuatan yang tercela itu pada pembuatnya, maka nyatalah bahwa hal dipidana atau tidaknya pembuat bukanlah bergantung pada apakah ada perbuatan pidana atau tidak, melainkan pada apakah terdakwa tercela atau tidak karena melakukan perbuatan pidana itu. Karena itulah maka juga dikatakan bahwa dasar dari adanya perbuatan pidana adalah asas legalitas yaitu asas yang menentukan bahwa sesuatu perbuatan adalah terlarang dan diancam dengan pidana barang siapa yang melakukannya, sedangkan dasar dari dipidananya pembuat adalah asas tidak dipidana jika tidak ada kesalahan.

$$
\text { Orang tidak mungkin }
$$
dipertanggungjawabkan dan dijatuhi pidana jika tidak melakukan perbuatan pidana. ${ }^{29}$ Tetapi meskipun dia melakukan perbuatan pidana, tidaklah selalu dapat dipidana. Orang yang melakukan perbuatan pidana akan dipidana apabila dia mempunyai kesalahan. Seseorang yang mempunyai kesalahan jika pada waktu melakukan perbuatan pidana, dilihat dari segi

\footnotetext{
${ }^{29}$ Mahrus Ali, Op.Cit., hal.86.
} 
Media Komunikasi dan Informasi Hukum dan Masyarakat

masyarakat dia dapat dicela oleh karenanya, sebab dianggap dapat berbuat lain jika memang tidak ingin berbuat demikian. ${ }^{30}$

Mempertanggungjawabkan terdakwa atas perbuatannya tidaklah ada gunanya jika perbuatannya itu sendiri tidaklah bersifat melawan hukum, maka dapat dikatakan bahwa terlebih dahulu harus ada kepastian tentang adanya perbuatan pidana dan kemudian semua unsur-unsur kesalahan tadi harus dihubungkan pula dengan perbuatan pidana yang dilakukan, sehingga untuk adanya kesalahan yang mengakibatkan dipidananya terdakwa maka terdakwa harus:

1. Melakukan perbuatan pidana;

2. Mampu bertanggung jawab;

3. Dengan kesengajaan atau kealpaan;

4. Tidak adanya alasan pemaaf. ${ }^{31}$

Dihubungkan dengan pertanggungjawaban pidana terhadap pelaku tindak pidana penyerobaan tanah, maka sanksi pidana bagi orang yang melakukan kejahatan tersebut adalah sebagaiana diatur dalam Pasal 385 KUHP yang merupakan satu-satunya pasal yang sering digunakan oleh pihak penyidik (Polisi) dan penuntut umum (Jaksa) untuk mendakwa pelaku penyerobotan tanah dan dikategorikan sebagai tindak pidana kejahatan. Khususnya Pasal 385 ayat (1) KUHP berbunyi : barangsiapa dengan maksud menguntungkan diri atau orang lain secara melawan hukum, menjual, menukarkan, atau membebani dengan credietverband sesuatu hak atas tanah, sesuatu gedung, bangunan, penanaman, atau pembenihan, padahal diketahui bahwa yang mempunyai atau turut mempunyai hak atasnya adalah orang lain.

\footnotetext{
${ }^{30}$ Moeljatno, Op.Cit, hal.2.

${ }^{31}$ Chairul Huda, Op.Cit, hal. 78
}

Faktor yang menjadi hambatan dalam penegakan hukum terhadap pelaku tindak pidana penyerobotan tanah yang menyebabkan sulitnya terselesaikan kasus penyerobotan tanah yaitu faktor internal dan faktor eksternalnya. Faktor Internal adalah faktor yang berasal dari dalam tubuh kepolisian. Faktorfaktor tersebut adalah sebagai berikut:

1. Faktor internal :

a. Personil penyidik kepolisian yang terbatas.

Pelaksanaan penyidikan terhadap tindak pidana penyerobotan tanah terhambat pada jumlah tim penyidik Kepolisian yang dimiliki. Jumlahnya sedikit atau kurang personil saja tidak sebanding dengan luas wilayah hukumnya.

b. Minimnya sarana dan fasilitas.

Faktor sarana dan fasilitas merupakan suatu hambatan yang dihadapi oleh pihak kepolisian. Faktor sarana dan fasilitas sendiri sehingga menyulitkan kepolisian dalam melakukan kegiatan atau operasi penyidikan.

c. Kurangnya ahlinya polisi dalam menangani kasus tindak pidana penyerobotan tanah.

Dalam menangani kasus tindak pidana penyerobotan tanah, polisi sebagai penegak hukum masih terkesan kurang ahli dalam menangani kasus tersebut. Hal ini terlihat ketika banyaknya kasus tindak pidana penyerobotan tanah yang tidak selesai begitu saja bahkan ada kasus yang ditutup, dan tanpa proses hukum selanjutnya.

d. Lemahnya aturan dan sanksi hukum. 
Media Komunikasi dan Informasi Hukum dan Masyarakat

Salah satu penyebab mengapa konflik pertanahan adalah karena lemahnya substansi hukum yang mengatur tindak pidana penyerobotan lahan. Selain lemah, prosedur beracara di level penyelidikan dan penyidikan juga sangat merepotkan sehingga penyerobotan tanah milik warga atau tanah ulayat oleh korporasi makin merajalela dan akhirnya menimbulkan konflik horizontal yang mematikan.

Lemahnya hukum tindak pidana penyerobotan lahan setidaknya terlihat dalam dua hal. Pertama, logika hukum dari pasalpasalnya tidak konsisten satu sama lain dan, kedua, ancaman pasal dari tindak pidana bersangkutan sangat rendah dan nyaris tidak masuk akal sehingga masyarakat tidak mau membawa kasus demikian ke proses hukum. Misalnya seseorang menyerobot atau menguasai atau mengganggu tanah milik si $\mathrm{A}$, tanpa izin, misalnya, maka si pelaku hanya diancam pidana 3 (tiga) bulan saja maksimal dan/atau denda paling banyak Rp.5.000 (lima ribu rupiah). Hal ini sebagaimana diatur dan diancam pidana dalam Pasal 6 UU No 51 Prp Tahun 1960 tentang Larangan Pemakaian Tanah Tanpa ljin yang Berhak atau Kuasanya.

Dalam hal tanah yang diserobot belum bersertifikat, lalu tanah yang diserobot tersebut disewakan oleh si penyerobot, atau dibebaninya hak tanggungan, atau dijual, atau ditukarkan, maka ancaman pasalnya lebih berat. Tindak pidana kategori ini diancam 4 (empat) tahun penjara, sebagaimana ditentukan Pasal 385 KUHP. Dengan logika pasal demikian maka seseorang yang berniat jahat atau beritikad tidak baik akan enak saja menyerobot tanah orang karena ancaman pasalnya cuma tiga bulan. Jika penyerobotan lahan ini dilakukan sistematis oleh investor besar berbadan hukum, maka, makin sulit lagi pertanggungjawaban hukumnya.

Penyerobotan lahan demikian dilaporkan ke kepolisian maka akan sangat merepotkan. Penyerobotan lahan akan terkait dengan batas-batas tertentu yang pasti ukurannya. Untuk memastikan batas-batas demikian diperlukan pengukuran oleh Badan Pertanahan Nasional (BPN). Dalam praktik, untuk meminta pengukuran ini ada pula prosedur dan biaya-biayanya di BPN, meliputi biaya administrasi dan biaya penggantian ongkos transpor dari juru ukur. Proses di BPN ini sudah tentu memakan waktu, belum lagi proses pengukuran di lapangan yang rawan konflik. Karena itu, biasanya, akan diminta pengamanan dari pihak aparat kepolisian.

\section{Faktor Eksternal :}

a. Kesulitan dalam memanggil saksi.

Kepolisian dalam memanggil para saksikhusus tindak pidanapenyerobotan tanah, Kepolisianmendapat kesulitan, karena saksi berdomisili tidak ditempat yang dituju (pindah tempat tinggal) yang menetapkan bahwa polisi harus menyelidiki tempat domisili yang baru dari saksi tersebut dan ada juga saksi 
Media Komunikasi dan Informasi Hukum dan Masyarakat

yang telah meninggal dunia dan pihak penyidik kepolisian harus mencari ahli waris dari pemilik tanah tersebut. Dalam hal ini sangat menghambat kelancaran proses penyidikan pihak kepolisian dan tidak hanya itu, meskipun saksi telah dapat ditentukan oleh polisi namun polisi juga mendapatkan kesulitan dalam memanggil saksi-saksi itu untuk kepentingan penyidikan. Sering mereka tidak memenuhi panggilan pihak kepolisian, karena alasanya jauhnya tempat tinggal ke Kantor Kepolisian karena kebanyakan saksi tidak berdomisili di tempat peristiwa pidana terjadi.

b. Kesulitan mencari keterangan ahli.

Dalam kasus penyerobotan tanah ini memerlukan keterangan seorang yang ahli dalam bidang pertanahan, biasanya seseorang yang ahli pertanahan ini berasal dari Badan Pertanahan Nasional Kota, karena banyak dari pihak penyidik Kepolisian itu sendiri tidak begitu paham dengan pertanahan untuk membuat terang suatu tindak pidana tersebut. Dengan adanya seseorang yang ahli dalam kasus tindak pidana penyerobotan tanah ini dapat mengetahui siapa yang mempunyai hak atas tanah tersebut.

c. Pihak pelapor lama melakukan laporan ke polisi setelah terjadinya tindak pidana. Pihak pelapor sendiri lama melakukan laporan ke polisi, sehingga para pelaku dapat saja melakukan berbagai macam hal seperti menghilangkan barang bukti.
Mengingat upaya penanggulangan kejahatan lewat jalur nonpenal lebih bersifat pencegahan untuk terjadinya kejahatan, maka sasaran utamanya adalah menangani faktorfaktor kondusif penyebab terjadinya kejahatan. Faktor-faktor kondusif antara lain berpusat pada masalah-masalah atau kondisi-kondisi sosial yang secara langsung atau tidak langsung dapat menimbulkan kejahatan. Dengan demikian dilihat dari sudut politik kriminal secara makro dan global, maka upaya-upaya non penal menduduki posisi kunci dan strategis dalam menanggulangi sebab-sebab dan kondisikondisi yang menimbulkan kejahatan.

\section{Usaha-usaha penanggulangan} kejahatan secara preventif sebenarnya bukan hanya bidang dari kepolisian saja. Penanggulangan kejahatan dalam arti yang umum secara tidak langsung juga dapat dilakukan tanpa menggunakan sarana pidana (sarana non penal) atau hukum pidana (sarana penal). Untuk sarana non penal misalnya usahausaha yang dilakukan departemen sosial dengan karang tarunanya tempat kegiatan para remaja untuk mengisi waktu luangnya dengan hal-hal yang positif, ini dapat menghindarkan dari hal-hal yang bersifat negatif.

\section{Penutup}

\section{A. Kesimpulan}

1. Pengaturan tindak pidana penyerobotan tanah diatur dalam beberapa ketentuan peraturan perundang-undangan, diantaranya Undang-Undang Nomor 51 Prp. Tahun 1960 menyatakan bahwa pemakaian tanah tanpa izin yang berhak atau kuasanya yang sah adalah perbuatan yang dilarang dan diancam dengan hukuman pidana (Pasal 2 dan Pasal 6) serta diatur dalam Kitab Undang-Undang Hukum Pidana pada 
Media Komunikasi dan Informasi Hukum dan Masyarakat

beberapa pasal yaitu Pasal 167, Pasal 242, Pasal, Pasal 263, Pasal 264, Pasal 266, Pasal 274, serta Pasal 385 KUHP.

2. Penegakan hukum terhadap tindak pidana penyerobotan tanah adalah dikenakan Pasal 385 KUHP yang merupakan satusatunya pasal yang langsung terkait penyerobotan tanah dan dikatagorikan sebagai tindak pidana kejahatan. Khususnya pada Pasal 385 ayat (1) KUHP yang berbunyi : "barang siapa dengan maksud menguntungkan diri sendiri atau orang lain secara melawan hukum, menjual, menukarkan atau membebani dengan crediet verband sesuatu hak atas tanah Indonesia, sesuatu gedung, bangunan, penanaman atau pembenihan, padahal diketahui bahwa yang mempunyai atau turut mempunyai hak atasnya adalah orang lain.

\section{B. Saran}

1. Hendaknya dalam perumusan aturan hukum terhadap perbuatan tindak pidana penyerobotan tanah lebih dikhusus lagi dan di tentukan terlebih dahulu kualifikasi bentuk tindak pidana nya yang akan dikenakan ketika ingin mendakwa seseorang atas perbuatan tindak pidana penyerobotan tanah yang dilakukan.

2. Hendaknya perbuatan penyerobotan tanah yang dilakukan oleh seseorang dapat diproses dan dijerat dengan pasal-pasal yang terdapat dalam Undang-Undang Nomor 51 PRP Tahun 1960 tentang Larangan Pemakaian Tanah Tanpa Izin dan di dalam KUHP. Penegakkan hukum melalui aturan ini diharapkan dapat memberi rasa keadilan dan kepastian hukum. Diperlukan pula pemahaman yang mendalam terlebih oleh penegak hukum mengenai peran ideal hukum bagi pemberlakuan hukum dalam masyarakat.

\section{Daftar Pustaka}

\section{A. Buku}

Abdurrahman, Muslan, Sosiologi dan Metode Penelitian Hukum, UMM Press, Malang, 2009.

Ali, Mahrus, Dasar-Dasar Hukum Pidana, Sinar Grafika, Jakarta, 2016.

Andrisman, Tri, Asas-Asas dan Aturan Umum Hukum Pidana Indonesia, Universitas Lampung, Bandar Lampung.

Arief, Barda Nawawi, Bungai Rampai Kebijakan Hukum Pidana, Citra Aditya Bakti, Bandung, 2009

Hamdan, M. Tindak Pidana Suap dan Money Politic. Pustaka Bangsa Press, Medan, 2013.

Harsono, Boedi, Hukum Agraria Indonesia, Syarat Pembentukan Undang-Undang Pokok Agraria, Isi Dan Pelaksanaannya, Djambatan, Jakarta, 2014.

Huda, Chairul , Dari Tiada Pidana Tanpa Kesalahan Menuju Kepada Tiada Pertanggungjawaban Pidana Tanpa Kesalahan, Prenada Media Group, . Jakarta, 2014

Ibrahim, Jhony ,Teori dan Metodologi Penelitian Hukum Normatif, Bayumedia, Surabaya, 2008

Jaya,Nyoman Serikat Putra, Relevansi Hukum Pidana Adat Dalam Pembaharuan Hukum Pidana Nasional, Citra Aditya Bakti, Bandung, 2006.

Jamilah, Firotin, Kitab Undang-Undang Hukum Pidana. Dunia Cerdas, Jakarta, 2016.

Kartono, Kartini, Pathologi Sosial, RajaGrafindo, Jakarta, 2015

Latif, Abdul, Hukum Administrasi Dalam Praktik Tindak Pidana Korupsi, Kencana Prenada Media, Jakarta, 2014.

Lamintang, PAF. dan Lamintang Theo, Delikdelik Khusus Kejahatan terhadap Harta Kekayaan, Sinar Grafika, Jakarta, 2009. 
Lamintang, PAF. dan G. Djisman Samosir, Hukum Pidana Indonesia, Sinar Baru, Bandung, 2009.

Lamintang, PAF. Dasar-Dasar Hukum Pidana Indonesia. Citra Adityta Bakti, Bandung, 2014

Maramis, Frans, Hukum Pidana Umum dan Tertulis di Indonesia. Raja Grafindo Persada, Jakarta, 2012.

Marpaung, Leden, Asas-Teori-Praktik Hukum Pidana, Sinar Grafika, Jakarta, 2005.

Marzuki, Peter Mahmud,Penelitian Hukum, Kencana, Jakarta, 2006.

Moeljatno, Asas-Asas Hukum Pidana, Bina Aksara, Jakarta, 2016.

Muhammad, Bushar, Pengantar Hukum Adat, Balai Buku Ichtiar, Jakarta, 2011.

Muladi,Lembaga Pidana Bersyarat, Alumni, Bandung, 2016.

Nasution,Bismar, Metode Penelitian Hukum Normatif dan Perbandingan Hukum, Fakultas Hukum Universitas Sumatera Utara, 2013.

Prakoso, Djoko, Pembaharuan Hukum Pidana di Indonesia, Liberty, Yogyakarta, 2017

Prasetyo, Teguh dan Abdul Halim Barkatullah, Politik Hukum Pidana Kajian Kebijakan Kriminalisasi dan Dekriminalisasi, Pustaka Pelajar, Yogyakarta, 2005.

Prasetyo, Teguh, Kriminalisasi dalam Hukum Pidana,: Nusa Media, . Bandung, 2011

Sianturi, SR. Tindak Pidana di KUHP Berikut Uraiannya, Alumni AHAEM-PETEHAEM, Jakarta, 2009

Simorangkir dkk. C. T., Kamus Hukum, Sinar Grafika, Jakarta, 2002.

Sudarto,Hukum dan Hukum Pidana, Alumni, Bandung, 2007.

Soekanto, Soerjono,Pengantar Penelitian Hukum, UI Press, Jakarta, 2016.

; Faktor-Faktor yang Mempengaruhi Penegeakan Hukum, Raja Grafindo Persada, Jakarta, 2014.
Soekanto, Soerjono dan Sri Mahmudji, Penelitian Hukum Normatif Suatu Tinjauan Singkat, Raja Grafindo Persada, Jakarta, 2014.

Soesilo, R. KUHP Serta Komentarkomentarnya Lengkap Pasal demi Pasal, Politea, Bogor, 2006.

Waluyo, Bambang, Pidana dan Pemidanaan, Sinar Grafika, Jakarta, 2016.

Winardi, Manajemen Konflik (Konflik Perubahan Dan Pengembangan), Mandar Maju, Bandung, 2007.

\section{B. Jurnal/Internet}

Ahmad, Ibrahim, Prinsip Keadilan Dalam Penyelesaian Sengketa Tanah untuk Kepentingan Pembangunan, Jurnal Legalitas, Vol 3 No 2, Tahun 2010.

Astuti, Galuh Faradhilah Yuni Relevansi Hukum Pidana Adat Dalam Pembaharuan Hukum Pidana di Indonesia, Jurnal Pandecta, Volume 10. Nomor 2. Desember 2018

Hairan, Kebijakan Formulasi Hukum Pidana Terhadap Tindak Pidana Pertanahan Di Indonesia, Jurnal Law Review Volume 3 No. 1 April 2020.

Pasaribu, Ivor Ignasio, "Penyerobotan Tanah Secara Tidak Sah Dalam Perspektif Pidana", tersedia pada http://www.hukumproperti.com, diakses pada hari Senin 18 Mei 2020 Pukul 21.00 Wib.

Ramadhani, Rahmat, Penanggulangan Kejahatan Terhadap Tanah, Jurnal Edutech Vol. 2 No. 2 September 2016.

Weku, Robert L. Kajian Terhadap Kasus Penyerobotan Tanah Ditinjau Dari Aspek Hukum Pidana dan Hukum Perdata, Jurnal, Lex Privatum Vol. 1 No. 2, AprilJuni 2018.

\section{Peraturan Peruundang-Undangan}

Kitab Undang-Undang Hukum Pidana

Undang-Undang Nomor 51 Tahun 1960 tentang Larangan Pemakaian Tanah Tanpa Izin yang Berhak atau Kuasanya. 